\title{
PERAN BPOM PROVINSI BALI DALAM MENINGKATKAN PERLINDUNGAN HUKUM TERKAIT PENJUALAN DONAT TANPA DICANTUMKANNYA TANGGAL KADALUARSA*
}

\author{
Oleh : \\ Eka Paulina Suliswati Putri** \\ I Made Subawa*** \\ Bagian Hukum Perdata Fakultas Hukum Universitas udayana
}

\begin{abstract}
Abstrak
Donat merupakan makanan yang bentuknya menyerupai cincin. Donat biasanya dibuat dengan campuran tepung terigu, telur, mentega dan yang lainnya. Pemasaran donat biasanya dijual di toko kue, warung pinggir jalan hingga ke sekolah-sekolah yang konsumennya merupakan anak-anak yang sangat menyukai rasa manis. Penjualan donat yang sangat laku dipasaran, tentu saja dimanfaatkan pelaku usaha yang curang dengan tidak mencantumkan komposisi bahan dan tanggal kadaluarsa yang tidak sesuai dengan Undang-Undang Nomor 8 Tahun 1999 tentang Perlindungan Konsumen serta untuk mengetahui akibat hukum terhadap pelaku usaha yang tidak mencantumkan komposisi bahan dan tanggal kadaluarsa. Metode penelitian empiris digunakan dalam penelitian ini. perlindungan konsumen terkait penjualan donat harus lebih ditingkatkan. Maka untuk meningkatkan pengawasan terhadap peredaran obat dan makanan yang tidak mencantumkan komposisi bahan dan tanggal kadaluarsa peran Balai Besar Badan Pengawas Obat dan Makanan Provinsi Bali sangat diperlukan. Perlindungan konsumen terkait dengan penjualan donat yang tidak mencantumkan komposisi bahan dan tanggal kadaluarsa telah diatur dalam Undang-Undang Nomor 8 Tahun 1999 tentang Perlindungan Konsumen. Kerugian dari konsumen jika mengkonsumsi makanan tanpa adanya komposisi bahan dan tanggal kadaluarsa, maka pelaku usaha wajib untuk bertanggung jawab.
\end{abstract}

Kata kunci: Perlindungan, konsumen, donat, informasi

\footnotetext{
Perlindungan Hukum Terhadap Terkait Penjualan Donat Tanpa Komposisi Bahan dan Pencantuman Tanggal Kadaluarsa merupakan makalah ilmiah di luar ringkasan skripsi.

** Eka Paulina Suliswati Putri adalah mahasiswi Fakultas Hukum Universitas Udayana. Korespondensi: Ekapaulinasp@gmail.com

${ }^{* * *}$ I Made Subawa adalah dosen Fakultas Hukum Universitas Udayana.
} 


\begin{abstract}
Donuts are foods that look like rings. Donuts are usually made with a mixture of flour, eggs, butter and others. Donut marketing is usually sold at cake shops, roadside stalls to schools where consumers are children who love sweetness. The sale of donuts that are highly marketable, of course, is used by fraudulent businessmen by not including the composition of ingredients and expiration dates that are not in accordance with Law Number 8 of 1999 concerning Consumer Protection and to find out the legal consequences of business actors who do not list the ingredients and expired date. Empirical research methods are used in this study. Consumer protection related to donut sales must be improved. So to improve supervision of the circulation of drugs and food that does not include the composition of the ingredients and the expiration date of the role of BPOM Bali Province is very necessary. Consumer protection related to the sale of donuts that do not include the composition of the ingredients and the expiration date has been regulated in Law Number 8 of 1999 concerning Consumer Protection. Losses from consumers if they consume food without the composition of ingredients and expiration date, then the business actor is obliged to be responsible.
\end{abstract}

Keywords: protection, consumers, donuts, information

\title{
I. Pendahuluan
}

\section{$1.1 \quad$ Latar Belakang}

Makanan ringan yang dijual dipasaran semakin hari semakin mengalami peningkatan yang signifikan. Berbagai hal untuk menarik perhatian konsumen dilakukan oleh pelaku usaha untuk menarik minat pembeli, mulai dari mendesain kemasan dengan warna-warna yang cantik hingga adanya keunikan bentuk dari produk tersebut. Rasa yang nikmat serta tampilan yang menarik tentu saja dapat dengan mudah membuat konsumen tertarik ingin mencoba makanan yang ditawarkan tersebut.

Salah satu makanan di Indonesia yang telah ada dipasaran sejak lama yaitu donat. Hampir setiap orang pasti pernah mencoba donat. Makanan yang terkenal dengan rasa manisnya ini 
memang sangat diminati oleh setiap kalangan, mulai dari anakanak hingga orang dewasa seringkali menjadikan donat sebagai makanan favorit mereka. Hal ini terbukti dari banyaknya terdapat toko serta tempat makan yang menawarkan donat sebagai menu utamanya. Biasanya donat disajikan sebagai makanan penutup atau sekedar camilan untuk bertemu teman.

Donat sendiri merupakan salah satu jenis makanan yang terbuat dari adonan tepung terigu, telur, gula dan mentega. Seluruh adonan tersebut kemudian dicampur dan diaduk hingga merata dan menghasilkan adonan yang sempurna. Setelah semua adonan tersebut jadi, adonan tersebut kemudian dibentuk menyerupai cincin atau bulat dengan lubang di bagian tengahnya, dan terakhir adonan tersebut di goring dalam minyak panas hingga matang. Untuk memberikan rasa lebih, donat tersebut biasanya ditaburi meises, krim, tepung gula, coklat dan sebagainya sesuai rasa yang disukai.

Berbeda dengan donat yang dijual di toko dengan harga yang lumayan mahal, biasanya donat-donat juga dijual di warung, di pasar, di emperan jalan hingga ke sekolah-sekolah yang dominan peminatnya adalah anak-anak sekolah dasar. Bahkan hingga kini keberadaan donat masih dijual dengan bebas dan dengan harga yang terjangkau antara 2000 rupiah hingga 5000 rupiah. Karena berbahan dasar tepung terigu, tentu saja donat dijadikan makanan pilihan saat merasa lapar karena mengandung karbohidrat yang sama dengan nasi. Biasanya donat-donat yang biasa kita lihat diwarung atau kantin sekolah itu merupakan donat yang tidak memiliki komposisi bahan serta tidak tercantumnya tanggal kadaluarsa yang kadang dapat membuat konsumen ragu untuk mengkonsumsi donat tersebut. 
Harga yang murah serta kurang telitinya konsumen membuat penyebaran donat tanpa komposisi bahan dan tanggal kadaluarsa tersebut dapat dengan bebas dijual dipasaran, padahal penyebaran donat tanpa komposisi bahan merupakan hal yang dapat membahayakan tubuh terutama bagi anak-anak yang biasanya belum mampu untuk membedakan makanan yang layak konsumsi dan makanan yang tidak layak untuk dikonsumsi. Seperti yang terjadi di Jawa Tengah tepatnya di Kecamatan Bawang Banjarnegara, sebanyak 35 murid SD Negeri Gemuruh Banjarnegara mual usai memakan donat yang dijual di kantin sekolah. Setelah mengkonsumsi donat-donat tersebut para siswa SD tersebut mengalami mual, muntah dan mengalami nyeri di daerah perut. ${ }^{1}$

Tentu saja bahaya dari makanan yang tidak jelas komposisi dan tanggal kadaluarsanya dapat membahayakan organ tubuh bahkan dapat menyebabkan kematian bagi seseorang. Kondisi yang sudah tidak layak digunakan ini tentu saja sudah tidak layak untuk dijual, dalam hal ini konsumen harus cerdas dan teliti dalam membeli suatu produk. ${ }^{2}$ Peran dari BPOM dalam melindungi konsumen agar tercegah dari berbagai kerugian akibat membeli suatu makanan harus terus ditingkatkan. Adanya jaminan kepastian akan suatu produk merupakan hak dari setiap konsumen, sebab adanya penyebaran produk tanpa informasi yang jelas dapat mengancam kesehatan konsumen. Untuk

${ }^{1}$ Khoirul Muzakki, 2018, "Diduga keracunan 35 murid SD N Gemuruh 3 Banjarnegara pusing dan mual usai makan donat.", URL http://www.tribunnews.com/regional/2018/10/19/diduga-keracunan-35murid-sdn-gemuruh-3-banjarnegara-pusing-dan-mual-usai-makan-donat, diakses tanggal 29 november 2018

${ }^{2}$ Luh Putu Budiarti, 2016, "Tanggung Jawab Pelaku Usaha Terhadap Penjualan Kosmetik Yang Tidak Disertai Dengan Kejelasan Label Produk di Denpasar", Kertha Semaya, Vol. 4 No. 3 April 2016, h.4, URL: https://ojs.unud.ac.id/index.php/kerthasemaya/article/view/20145 
menghindari hal tersebut dibuatlah peraturan perundangundangan guna melindungi hak dari konsumen agar dapat terus terjaga, dan peraturan tersebut dapat terus diterapkan selama tidak bertolak belakang dengan aturan lainnya. ${ }^{3}$

Maka dari itu penulis tertarik untuk meneliti mengenai Peran BPOM Provinsi Bali Terkait Penjualan Donat Tanpa Komposisi Bahan Dan Tanggal Kadaluarsa ditinjau dari UndangUndang Nomor 8 Tahun 1999 Tentang Perlindungan Konsumen, agar konsumen yang dirugikan dari penjualan donat tersebut dapat menuntut kembali haknya dan agar BPOM dapat terus meningkatkan pengawasannya terhadap penyebaran obat dan makanan yang tidak jelas informasi kandungannya.

\subsection{Rumusan Masalah}

1. Tanggung jawab pelaku usaha terhadap konsumen terkait peredaran donat tanpa tanggal kadaluarsa.

2. Peran Balai Besar Pengawas Obat dan Makanan Provinsi Bali terhadap produk makanan yang tidak mencantumkan tanggal kadaluarsa.

\subsection{Tujuan Penulisan}

Adapun tujuan dalam penelitian ini untuk mengetahui tanggung jawab pelaku usaha terhadap konsumen terkait peredaran donat tanpa tanggal kadaluarsa dan untuk mengetahui Peran Bali Besar Pengawas Obat dan Makanan Provinsi Bali terhadap produk makanan yang tidak mencantumkan tanggal kadaluarsa.

\section{Isi Makalah}

${ }^{3}$ Celina Tri Siwi Kristyanti, 2011, Hukum Perlindungan Konsumen, Sinar Grafika, Jakarta,h. 47 


\subsection{Metode penelitian}

Dalam penelitian ini menggunakan metode penelitian empiris dengan melakukan penelitian secara nyata apakah sudah benar adanya implementasi di masyarakat bagaimana hukum itu bekerja 4 Perlunya penelitian hukum empiris agar dapat mengetahui kenyataan yang ada di masyarakat terkait tanggung jawab pelaku usaha terhadap konsumen terkait peredaran donat tanpa tanggal kadaluarsa dan untuk mengetahui Peran Bali Besar Pengawas Obat dan Makanan Provinsi Bali terhadap produk makanan yang tidak mencantumkan tanggal kadaluarsa.

\subsection{Hasil dan analisis}

\subsubsection{Tanggung jawab pelaku usaha terkait peredaran donat tanpa tanggal kadaluarsa.}

Setiap usaha dari pelaku usaha untuk menjamin adanya kepastian hukum untuk memberi perlindungan kepada konsumen telah tertuang jelas di dalam Undang-Undang Nomor 8 Tahun 1999 Tentang Perlindungan Konsumen atau yang disingkat dengan UUPK. Pencantuman komposisi bahan dan tanggal kadaluarsa yang tertulis dengan jelas pada suatu produk yang dipasarkan terutama yang dikonsumsi merupakan kewajiban yang harus dilakukan oleh pelaku usaha, yang bertujuan agar konsumen mendapatkan haknya atas informasi yang sesuai dengan kenyataanya dan apa yang ada.

Hak konsumen adalah untuk mendapatkan informasi yang benar akan suatu produk, sehingga disaat konsumen tertarik dengan suatu produk ia akan langsung dapat membaca keterangan maupun tanggal kadaluarsa yang ada dalam produk

4 Soerjono Soekanto, 1986, Pengantar Penelitian Hukum, UI-Press, Jakarta, h. 15 
tersebut. ${ }^{5}$ Namun meskipun yang sudah jelas adanya, ternyata masih ada saja pelaku usaha nakal dan tidak bertanggung jawab yang tidak mencantumkan komposisi bahan dan tanggal kadaluarsa yang tentu saja dapat merugikan konsumen, sehingga perlindungan konsumen terkait penjualan donat harus lebih ditingkatkan. ${ }^{6}$ Maka untuk meningkatkan pengawasan terhadap peredaran obat dan makanan yang tidak mencantumkan komposisi bahan dan tanggal kadaluarsa peran BPOM Provinsi Bali sangat diperlukan. Adapun yang menjadi hak-hak konsumen berdasarkan UUPK tercantum dalam pasal 4 yang menyebutkan, bahwa yang menjadi Hak Konsumen adalah:

a. Di dalam mengkonsumsi barang dan/atau jasa konsumen memiliki hak atas kenyamanan, keamanan dan keselamatan;

b. Konsumen memiliki hak untuk memilih barang dan/atau jasa serta mendapatkan barang dan/atau jasa tersebut sesuai dengan nilai tukar dan kondisi serta jaminan yang dijanjikan;

c. Di dalam menjamin mengenai kondisi barang dan/atau jasa konsumen memiliki hak atas informasi yang benar, jelas dan jujur;

d. Berdasarkan atas barang dan/atau jasa yang digunakan konsumen memiliki hak untuk didengar pendapat dan keluhannya;

e. Hak untuk diberikan advokasi, perlindungan serta upaya penyelesaian sengketa perlindungan konsumen secara patut;

5 Husni Syawali dan Neni Sri Imaniyati, 2000, Hukum Perlindungan Konsumen, Mandar Maju, Bandung, h.18

6 Ahmadi Miru, 2013, Prinsip-prinsip Perlindungan Hukum bagi Konsumen di Indonesia, cet.2 Rajawali Pres, Jakarta, h. 102 
f. Hak untuk diberikan pendidikan konsumen dan pembinaan;

g. Di dalam memberikan pelayanan, konsumen memiliki hak untuk dilayani dan diperlakukan secara benar dan jujur serta tidak diskriminatif;

h. Apabila terdapat barang dan/atau jasa yang tidak diterima sesuai dengan perjanjian atau tidak sebagaimana mestinya, maka konsumen memiliki hak untuk mendapatkan kompensasi, ganti rugi dan/atau penggantian;

i. Hak-hak yang tercantum dalam ketentuan peraturan perundang-undangan lainnya.

Tanggung jawab pelaku usaha dalam penjualan donat tanpa pencantuman tanggal kadaluarsa termasuk ke dalam tanggung jawab mutlak (strict liability) atau yang dikenal dengan Product Liability. Dalam prinsip ini pelaku usaha wajib bertanggung jawab jika terdapat kerugian yang diderita konsumen akibat dari penggunaan produk yang dipasarkannya. ${ }^{7}$ Prinsip ini bertujuan untuk menjerat pelaku usaha yang menyebabkan kerugian bagi konsumennya. Adapun tanggung jawab konsumen telah diatur dalam UUPK yang terdapat pada pasal 19 yang menyatakan bahwa:

(1) Pelaku usaha bertanggung jawab memberikan ganti rugi atas kerusakan, pencemaran, dan atau kerugian konsumen akibat mengkonsumsi barang dan atau jasa yang dihasilkan atau diperdagangkan;

7 Ni Putu Januaryati Pande, 2017, "Perlindungan Konsumen Terhadap Produk Kosmetik Import Yang Tidak Terdaftar di BPOM Denpasar.", Jurnal Magister Hukum, Vol. 6, No. 1, Jurnal Magister Hukum, Fakultas Hukum, Universitas Udayana, Bali, h.3 
(2) Ganti rugi sebagaimana dimaksud pada ayat (1) dapat berupa pengembalian uang atau penggantian barang dan/atau jasa yang sejenis atau setara nilainya, atau perawatan kesehatan dan/atau pemberian santunan yang sesuai dengan ketentuan peraturan perundangundangan yang berlaku;

(3) Pemberian ganti rugi dilaksanakan dalam tenggang waktu 7 (tujuh) hari setelah tanggal transaksi.

(4) Pemberian ganti rugi sebagaimana dimaksud pada ayat (1) dan ayat (2) tidak menghapuskan kemungkinan adanya tuntutan pidana berdasarkan pembuktian lebih lanjut mengenai adanya unsur kesalahan;

(5) Ketentuan sebagaimana dimaksud pada ayat (1) dan ayat (2) tidak berlaku apabila pelaku usaha dapat membuktikan bahwa kesalahan tersebut merupakan kesalahan konsumen.

Berdasarkan yang tertuang dalam Pasal 19 diatas, maka setiap pelaku usaha wajib bertanggung jawab atas kerugian konsumen dengan memberikan kompensasi atau ganti rugi berupa pengembalian uang atau penggantian barang yang terkait dengan pemasaran donat yang tidak mencantumkan tanggal kadaluarsa. Apabila pelaku usaha yang telah terbukti merugikan konsumen tidak mau bertanggung jawab atas perbuatannya maka konsumen yang dirugikan dapat menggugat pelaku usaha melalui badan peradilan ditempat kedudukan konsumen tersebut sesuai dengan ketentuan yang ada dalam Pasal 23 UUPK. ${ }^{8}$

8 Ni Komang Ayu Nira Relies Rianti, 2017, “Tanggung Jawab Pelaku Usaha Terhadap Konsumen Dalam Hal Terjadinya Shortweighting Ditinjau Dari Undang-Undang Nomor 8 Tahun 1999 Tentang Perlindungan Konsumen.", Jurnal Magister Hukum, Vol. 6, No. 4, Jurnal Magister Hukum, Fakultas Hukum, Universitas Udayana, Bali, h.4 


\subsubsection{Peran Badan Pengawas Obat dan Makanan terhadap penyebaran donat tanpa tanggal kadaluarsa.}

BPOM adalah sebuah Lembaga Pemerintahan Non Kementerian (LPNK) yang bertugas mengawasi peredaran obat, obat tradisional, suplemen kesehatan, kosmetik dan makanan di wilayah Indonesia. Tugas, fungsi dan kewenangan BPOM diatur dalam Keputusan Presiden Nomor 103 Tahun 2001 tentang Kedudukan, Tugas, Fungsi, Kewenangan, Susunan Organisasi dan Tata Kerja Lembaga Pemerintah non Departemen yang telah diubah terakhir kali dengan Peraturan Presiden Nomor 3 Tahun 2013 tentang Perubahan Ketujuh atas Keputusan Presiden Nomor 103 Tahun 2001.Permasalahan mengenai produk makanan tanpa pencantuman tanggal kadaluarsa sampai saat ini masih sering dijumpai di masyarakat. Pengawasan terhadap peredaran makanan tanpa pencantuman tanggal kadaluarsa harus ditingkatkan untuk melindungi para konsumen sesuai dengan fungsi dan keberadaan dari BPOM Kota Denpasar mempunyai peran yang sangat penting dalam hal pembangunan kesehatan untuk melindungi dan mengawasi produk makanan yang beredar di kalangan masyarakat.

Dalam Pasal 1 Peraturan Badan Pengawas Obat dan Makanan menjelaskan bahwa BPOM adalah suatu lembaga pemerintahan yang mempunyai tugas untuk mengawasi obat dan makanan, dimana sejalan dengan isi dari asas dan tujuan dari UUPK yang untuk melindungi keselamatan konsumen. Dengan adanya pengaturan tersebut diharapkan setiap pelaku usaha dalam memberikan produk pangan senantiasa jujur sehingga tidak merugikan pihak konsumen. Berdasarkan keterangan Drs. I Wayan Eka Pranata, S. Farm, Apt. Kepala bidang Pemeriksaan dan Penyitaan, bahwa pada tahun 2017 telah dilakukan pemeriksaan 
terhadap produk-produk yang tidak mencantumkan tanggal kadaluarsa dan dilakukan penyitaan jika peredaran makanan yang tidak mengandung tanggal kadaluarsa dianggap membahayakan masyarakat (Wawancara tanggal 10 September 2018)

Adapun peran dari BPOM antara lain:

1. Pembinaan, tertuang di dalam Pasal 3 ayat (1) huruf $\mathrm{c}$ Peraturan BPOM yaitu proses sosialisasi atau edukasi terhadap penjualan makanan tanpa dicantumkannya tanggal kadaluarsa yang dilakukan melalui media sosial maupun pelatihan secara langsung, karena hal ini merupakan kegiatan yang sangat penting dilakukan untuk meningkatkan pengetahuan dari pihak konsumen sebelum membeli suatu produk pangan, dan untuk pihak produsen agar lebih memperhatikan kemasan, label, ijin dan yang paling penting memberikan keterangan yang sejujurnya terkait tanggal kadaluarsa suatu makanan.

2. Pengawasan hal tersebut tercantum dalam Pasal 2 Peraturan BPOM yang menyatakan bahwa BPOM terlibat dalam pengawasan pangan olahan. Dalam proses pengawasan yang dilakukan oleh BPOM melalui 2 cara yaitu Sistem Pengawasan Pre Market dan Post Market. Pre Market adalah pengawasan yang dilakukan sebelum produk tersebut diedarkan dikalangan masyarakat dengan menjamin mutu, efektivitas produk dan keamanan sehingga produk tersebut dinyatakan lolos untuk dipasarkan. Sedangkan Post Market adalah pengawasan yang dilakukan pada saat barang tersebut sudah beredar dikalangan masyarakat. 
3. Standarisasi, tertuang di dalam Pasal 3 ayat (1) huruf c Peraturan BPOM yaitu suatu proses untuk melakukan standarisasi dari suatu produk pangan yang dilakukan di pusat guna untuk tidak terjadinya standarisasi yang berbeda-beda antara satu pelaku usaha dan pelaku usaha lainnya. Standarisasi ini juga bertujuan untuk menekan kemungkinan adanya cacat produk.

Guna mendukung kelancaran pelayanan informasi publik diperlukan Standard Operating Procedure (SOP) sebagai panduan PPID dalam melaksanakan tugas layanan informasi. Badan POM telah memiliki Standard Operating Procedure (SOP) tentang Layanan Informasi dan Layanan Pengaduan

1. POM-06.SOP.01 Layanan Informasi Prosedur ini menjelaskan tanggung jawab dan langkah-langkah pelayanan informasi di unit-unit yang melakukan layanan informasi, termasuk Pejabat Pengelola Informasi dan Dokumentasi (PPID). Layanan informasi dapat dilakukan melalui telepon, surat, faksimil, email, SMS, website, dan datang langsung, baik dari pihak eksternal/masyarakat atau dari pihak internal. SOP ini bertujuan untuk:

a. memberikan standar bagi Badan POM dalam melaksanakan pelayanan Informasi termasuk informasi publik

b. meningkatkan pelayanan Informasi di lingkungan Badan POM untuk menghasilkan layanan informasi yang berkualitas, cepat, tepat waktu, biaya ringan, dan cara sederhana 
c. menjamin pemenuhan hak warga negara untuk memperoleh akses informasi publik

d. menjamin terwujudnya tujuan penyelenggaraan keterbukaan informasi sebagaimana diatur dalam Undang-Undang Keterbukaan Informasi Publik.

2. POM-06.SOP.04 Layanan Pengaduan Prosedur ini bertujuan untuk:

a. Terbentuknya akses kebutuhan masyarakat terhadap layanan informasi dalam rangka melindungi masyarakat dari Obat dan Makananyang tidak memenuhi syarat keamanan, khasiat, dan mutu.

b. Terlayaninya pengaduan masyarakat berkaitan dengan keamanan, khasiat, dan mutu Obat dan Makanan untuk dilakukan pemecahan masalah secara cepat, tepat dan akurat, melalui prosedur dan tatanan organisasi yang telah ada.

c. Tersedianya berbagai data dan informasi yang berasal dari pengaduan masyarakat sebagai bahan untuk meningkatkan pengawasan Obat dan Makanan.

d. Tersedianya mekanisme penelusuran data/referensi dan mekanisme rujukan ke unit terkait.

e. Tersedia akses bagi Masyarakat untuk memberikan masukan terhadap peningkatan pelayanan Unit Layanan Pengaduan Konsumen. 
Pelaku usaha yang tidak mencantumkan komposisi bahan dan tanggal kadaluarsa sudah dengan jelas melanggar ketentuan di dalam UUPK, dan apabila terdapat kerugian yang diterima oleh konsumen maka pelaku usaha harus bertanggung jawab. Kerugian yang diterima oleh konsumen tentu saja karena tidak sesuainya produk yang diperjanjikan serta adanya kesalahan dari pelaku usaha yang tentu saja dapat membahayakan kesehatan konsumen. UUPK dan Undang-Undang Kesehatan merupakan aturan yang digunakan untuk menjerat pelaku usaha yang menyebabkan konsumen mengalami kerugian.

Drs. I Wayan Eka Pranata, S.Farm, Apt selaku Kepala Bidang Pemeriksaan dan Penyitaan menyatakan selain tugas pokoknya sebagai pengawas terhadap produk pangan yang tersebar di masyarakat, juga melakukan fungsi sertifikasi dan layanan informasi (Wawancara tanggal 10 September 2018)

\section{PENUTUP}

\subsection{Kesimpulan}

1. Apabila terdapat kerugian yang diterima oleh konsumen maka pelaku usaha harus bertanggung jawab. Kerugian yang diterima oleh konsumen tentu saja karena tidak sesuainya produk yang diperjanjikan serta adanya kesalahan dari pelaku usaha yang tentu saja dapat membahayakan kesehatan konsumen. UUPK dan Undang-Undang Kesehatan merupakan aturan yang digunakan untuk menjerat pelaku usaha yang menyebabkan konsumen mengalami kerugian.

2. Peran dari BPOM untuk meningkatkan perlindungan hukum terkait penjualan donat tanpa komposisi bahan dan tanggal kadaluarsa harus terus ditingkatkan yaitu dengan memaksimalkan pembinaan, pengawasan dan standarisasi sesuai dengan Peraturan Badan Pengawas Obat dan Makanan. 
Dengan adanya pengaturan tersebut diharapkan setiap pelaku usaha dalam memberikan produk pangan senantiasa jujur sehingga tidak merugikan pihak konsumen.

\subsection{Saran}

1. Sebaiknya dengan banyaknya kasus mengenai penjualan donat tanpa komposisi bahan dan tanggal kadaluarsa membuat konsumen harus lebih cerdas dan cermat dalam membeli produk tersebut. Itikad baik, memberikan informasi yang jelas, benar dan jujur atas barang yang diedarkan dengan memperhatikan hak-hak konsumen merupakan kewajiban dari pelaku usaha.

2. Semestinya peran pemerintah lebih di maksimalkan lagi khususnya BPOM di dalam mewujudkan kepastian hukum untuk mengoptimalkan hak dari konsumen sangat diperlukan karena pada kenyataanya masih banyak konsumen yang tidak mengetahui adanya aturan untuk menuntut hak-hak jika terdapat konsumen yang dirugikan.

\section{DAFTAR PUSTAKA}

\section{Buku}

Imaniyati Sri, Neni dan Husni Syawali, 2000, Hukum Perlindungan Konsumen, Mandar Maju, Bandung.

Miru, Ahmadi, 2013, Prinsip-prinsip Perlindungan Hukum bagi Konsumen di Indonesia, cet.2. Rajawali Pres, Jakarta.

Shidarta, 2000, Hukum Perlindungan Konsumen, Grasindo, Jakarta.

Soerjono Soekanto, 1986, Pengantar Penelitian Hukum, UI-Press, Jakarta.

Sutedi, Adrian, 2008, Tanggung Jawab Produk Dalam Perlindungan Konsumen, Ghalia Indonesia, Bogor. 
Tri Siwi Kristiyanti, Celina, 2014, Hukum Perlindungan Konsumen, Sinar Grafika, Jakarta.

\section{Jurnal :}

Ni Putu Januaryati Pande, 2017, "Perlindungan Konsumen Terhadap Produk Kosmetik Import Yang Tidak Terdaftar di BPOM Denpasar.", Jurnal Magister Hukum, Vol. 6, No. 1, Jurnal Magister Hukum, Fakultas Hukum, Universitas Udayana, Bali.

Luh Putu Budiarti, 2016, “Tanggung Jawab Pelaku Usaha Terhadap Penjualan Kosmetik Yang Tidak Disertai Dengan Kejelasan Label Produk di Denpasar", Kertha Semaya, Vol. 4 No. 3 April 2016, Fakultas Hukum, Universitas Udayana, Bali.

Ni Komang Ayu Nira Relies Rianti, 2017, “Tanggung Jawab Pelaku Usaha Terhadap Konsumen Dalam Hal Terjadinya Shortweighting Ditinjau Dari Undang-Undang Nomor 8 Tahun 1999 Tentang Perlindungan Konsumen.”, Jurnal Magister Hukum, Vol. 6, No. 4, Jurnal Magister Hukum, Fakultas Hukum, Universitas Udayana, Bali.

\section{Internet :}

Khoirul Muzakki, 2018, "Diduga keracunan 35 murid SD N Gemuruh 3 Banjarnegara pusing dan mual usai makan donat.", URL http://www.tribunnews.com/regional/2018/10/19/didugakeracunan-35-murid-sdn-gemuruh-3-banjarnegara-pusing-danmual-usai-makan-donat, diakses tanggal 29 november 2018

\section{Peraturan Perundang-Undangan :}

Undang-Undang Nomor 8 Tahun 1999 tentang Perlindungan Konsumen (Lembaran Negara Republik Indonesia tahun 1999 Nomor 42 Tambahan Lembaran Negara Republik Indonesia Nomor 3821) 